\title{
PHYTOCHEMICAL SCREENING AND ANTIHYPERGLYCEMIC ACTIVITY OF ETHANOLIC EXTRACT OF Coriandrum sativum L. LEAF
}

\author{
S.M. Sinaga ${ }^{1, *}$, G. Haro ${ }^{1}$, S. Sudarmi ${ }^{1}$ and Iksen ${ }^{2}$ \\ ${ }^{1}$ Department of Pharmaceutical Chemistry, Faculty of Pharmacy, Universitas Sumatera Utara, \\ Medan-20155, Indonesia \\ ${ }^{2}$ Department of Pharmacy, Sekolah Tinggi Ilmu Kesehatan Senior Medan, \\ Medan-20141, Indonesia \\ *E-mail: sitimorinsinaga28@gmail.com
}

\begin{abstract}
The synthetic drugs for DM treatment are available in the market, but they have side effects in long term treatment. This makes a research about effective natural resources to reduce diabetes intensity are rampant, one of them is Coriander leaf (Coriandrum sativum L). Ethanolic extract of coriander leaf (EECL) was tested for phytochemical screening and anti-diabetic activity, by glucose tolerance test in normal rats and alloxan-induced diabetic mice. The mice were divided into five groups of six animals each (diabetic control, standard drug-treated, and plant treated groups $(100,20$ and $400 \mathrm{mg} / \mathrm{kg} \mathrm{bw}))$. On the $0^{\text {th }}, 3^{\text {th }}, 6^{\text {th }}, 9^{\text {th }}, 12^{\text {th }}$ and $15^{\text {th }}$ days, the blood samples were analyzed for blood glucose.The results of phytochemical screening showed that EELC has a lot of phytochemical compounds such as alkaloids, flavonoids, tannins, glycosides, saponins and steroids. Antihyperglycemic study showed that there were not have significant differences between EECL and metformin $65 \mathrm{mg} / \mathrm{kg}$ bw group. Based on the research investigation, it can be concluded that EELChas an antihyperglicemia effect.
\end{abstract}

Keywords: Coriander, Alloxan, Antihyperglicemic, Extract, Ethanolic

(c) RASĀYAN. All rights reserved

\section{INTRODUCTION}

Hyperglycemia is a medical condition in the form of an increase in blood glucose levels exceeding the normal limit. Hyperglycemia is one of the typical signs of diabetes mellitus (DM), although it may also be found in several other conditions. ${ }^{1}$ Treatment of DM disease by using two groups of drugs, namely insulin and oral drugs that have hypoglycemic effects such as glibenclamide, tolbutamide, and metformin. These synthetic drugs are available on the market, but in the long term will have side effects. ${ }^{2}$ Side effects of these drugs could be included hypoglycemia and digestive disorders. ${ }^{3}$ This makes research on natural ingredients that are effective in reducing the intensity of diabetes is being carried out. ${ }^{4}$ One of these plants is Coriander (Coriandrum sativum L.), whose leaf parts have been used in many traditional medicine systems to treat some diseases.There are a large number of compounds isolated from Coriander, including flavonoids (quercetin), polyphenols, $\beta$-carotene, cineol, coumarin, and tannins. Traditionally, coriander is used for the treatment of antiseptic, gastrointestinal complications, and antidiabetes. ${ }^{5}$ The aim of this study is to investigate the phytochemical compounds in EELC and evaluate the antihyperglycemic activity on alloxan-induced diabetic mice.

\section{Sample Collection}

\section{EXPERIMENTAL}

Fresh leaf of Coriander (Coriandrum sativum L.), were collected from the local market of Medan (Indonesia). The plant specimen was identified and authenticated by the Herbarium Medanense (MEDA) Universitas Sumatera Utara (No: 3928/MEDA/2019). Fresh leaf of coriander was dried in open air without exposure to direct sunlight and then the dried sample was powdered by mechanical milled.

Rasayan J. Chem., 12(4), 1992-1996(2019)

http://dx.doi.org/10.31788/RJC.2019.1245451

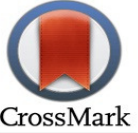




\section{Extract Preparation}

Extract of coriander leaf was prepared by the ethanolic solvent by using maceration method for 5 days. About $300 \mathrm{~g}$ of the fine powder coriander leaf was extracted with $96 \%$ ethanol by using maceration for 5 days at room temperature. The ethanol extract of coriander leaf (EECL) solution part was evaporated by using rotary evaporator to get the crude extract. ${ }^{6,7}$

\section{Preliminary Phytochemical Screening}

The crude extract of EELC was screening by using the standard protocol to know the presence of phytochemical compounds. ${ }^{8}$

\section{Animals Preparation}

Healthy adult male mice ( $\pm 20 \mathrm{~g}$ of body weight) were obtained from Animal House of Faculty of Pharmacy, Universitas Sumatera Utara. Mice were housed in polycarbonate cages at room temperature with 12 hrs day-night circle. The mice were fed on a standard animal pellet and water freely. This study was approved by AREC No: 00141/KEPH-FMIPA/2019) which the experiments were conducted according to the ethical norms by AREC. ${ }^{9}$ The animals were fasted for $12 \mathrm{~h}$ before experimentation but allowed free access to water.

\section{Oral Glucose Tolerance Test}

This method was using fasted mice which are divided into 5 groups of six male mice each. Group I as the control group (Na CMC 0.5\%), Group II-IV received EECL respectively at dose 100, 200 and $400 \mathrm{mg} / \mathrm{kg}$ bw. Group V received glibenclamide $0.65 \mathrm{mg} / \mathrm{kg}$ bw. All the mice from these 5 groups were given glucose $(3 \mathrm{~g} / \mathrm{kg}$ bw) by p.o 30 mins after administration of the Na CMC, EECL and glibenclamide. Blood samples were collected at 30, 60, 90 and $120 \mathrm{~min}$ after the glucose loading and measured by glucometer.

\section{Alloxan Induced Test}

Male mice were induced diabetic (hyperglycemia) by a single i.p injection of alloxan (160 mg/kg bw) After 3 days, blood samples were collected to confirm the development of hyperglycemic activity. These diabetic mice then divided into 5 groups which are group I as control group (Na CMC 0.5\%), Group II-IV received EECL respectively at dose 100, 200 and $400 \mathrm{mg} / \mathrm{kg}$ bw. Group V received metformin 0.65 $\mathrm{mg} / \mathrm{kg}$ bw. Blood samples were collected and measured respectively at $0^{\text {th }}, 3^{\text {th }}, 6^{\text {th }}, 9^{\text {th }}, 12^{\text {th }}$ and $15^{\text {th }}$ days by using glucometer.

\section{Statistic Analysis}

All the data were expressed as mean \pm SEM. The significant difference of data between different groups was compared by ANOVA followed by Post Hoc Tukey HSD test.

\section{Preliminary Phytochemical Screening}

\section{RESULTS AND DISCUSSION}

Preliminary phytochemical screening was tested by standard procedure on the EECL. Table-1 showed the result of phytochemical screening. Alkaloids, flavonoids, tannins, glycosides, saponins and steroids are present in EECL. All of these phytochemical compounds are predicted to have a beneficial pharmacological effect to us. ${ }^{9}$

Table-1: Preliminary Phytochemical Screening of EECL

\begin{tabular}{c|c|c}
\hline Phytochemical Compounds & Test & Results \\
\hline Alkaloids & Mayer Test & Positive \\
\cline { 2 - 3 } & Bouchardat Test & Positive \\
\cline { 2 - 3 } & Dragendorff Test & Positive \\
\hline Flavonoids & Shinoda Test & Positive \\
\hline Saponins & Froth Forming Test & Positive \\
\hline Glycosides & Glycosides Test & Positive \\
\hline Steroids & Liebermann-Burchard Test & Positive \\
\hline
\end{tabular}


RASĀYAN J. Chem.

Vol. 12 | No. 4 |1992 - 1996| October - December | 2019

\section{Oral Glucose Tolerance Test}

From the results of the Post Hoc Tukey HSD statistical analysis at 120 minutes (Table-2), it was found that the EECL group 100, 200, and $400 \mathrm{mg} / \mathrm{kg}$ bw did not have a significant difference with the glibenclamide group $0.65 \mathrm{mg} / \mathrm{kg}$ bw (p> 0.05). This shows that EECL 100, 200, and $400 \mathrm{mg} / \mathrm{kg} \mathrm{bw}$ resembles the antihyperglycemic glibenclamide effect and can reduce the glucose level of mice.

Table-2: Oral Glucose Tolerance Test Result

\begin{tabular}{|c|c|c|c|c|c|}
\hline \multirow[t]{3}{*}{ Group } & \multicolumn{5}{|c|}{ Average Blood Sugar Level (mg/dL) } \\
\hline & & & Time $(\min )$ & & \\
\hline & 0 (fasting) & 30 & 60 & 90 & 120 \\
\hline $\begin{array}{c}\mathrm{Na}-\mathrm{CMC} \\
0.5 \%\end{array}$ & $84 \pm 3.80$ & $\begin{array}{c}257.75 \pm \\
10.64 * b\end{array}$ & $294.75 \pm 24.67$ & $251 \pm 13.08 * b$ & $\begin{array}{c}238.75 \pm \\
14.66 * b\end{array}$ \\
\hline $\begin{array}{c}\text { EECL } \\
100 \mathrm{mg} / \mathrm{kg} \text { bb }\end{array}$ & $88.75 \pm 4.64$ & $\begin{array}{l}249.25 \pm \\
42.63 * b\end{array}$ & $261 \pm 95.48 * b$ & $211 \pm 72.73 * b$ & $\begin{array}{c}92.25 \pm \\
16.963 * b\end{array}$ \\
\hline $\begin{array}{c}\text { EECL } \\
200 \mathrm{mg} / \mathrm{kg} \text { bb }\end{array}$ & $83.25 \pm 5.36$ & $\begin{array}{l}222.25 \pm \\
37.21 * b\end{array}$ & $222 \pm 31.21 * b$ & $\begin{array}{c}122.5 \pm \\
8.22\end{array}$ & $95.5 \pm 5.95 * a$ \\
\hline $\begin{array}{c}\text { EECL } \\
400 \mathrm{mg} / \mathrm{kg} \mathrm{bb}\end{array}$ & $81.75 \pm 5.39$ & $\begin{array}{l}289.25 \pm \\
61.92 * b\end{array}$ & $\begin{array}{l}199.75 \pm \\
67.32 * \mathrm{~b}\end{array}$ & $\begin{array}{c}116.5 \pm \\
15.26\end{array}$ & $79.25 \pm 7.97 * a$ \\
\hline $\begin{array}{l}\text { Glibenclamide } \\
0.65 \mathrm{mg} / \mathrm{kg} \mathrm{bb}\end{array}$ & $82.5 \pm 3.77$ & $\begin{array}{l}128 \pm \\
13.12\end{array}$ & $\begin{array}{l}82.25 \pm \\
6.83\end{array}$ & $\begin{array}{l}74.5 \pm \\
7.63 * a\end{array}$ & $63.5 \pm 2.87 * \mathrm{a}$ \\
\hline
\end{tabular}

Values are given as mean \pm SEM for six mice in each group. $*$ a $\mathrm{P}<0.05$ significat difference compared with NaCMC $0.5 \%$. *b $\mathrm{P}<0.05$ significant difference compared with glibenclamide.

\section{Alloxan Induced Test}

Based on the Fig.-1, it can be concluded that EECL groups were able to reduce the blood glucose of mice induced by alloxan. The decreased in blood glucose with EECL therapy can be caused by the presence of bioactive compounds contained in EECL which can prevent the oxidation of pancreatic beta cells due to the induction of alloxan so that damage can be minimized. Bioactive compounds contained in EECL included flavonoids, alkaloids, saponins, tannins, glycosides, and steroids.

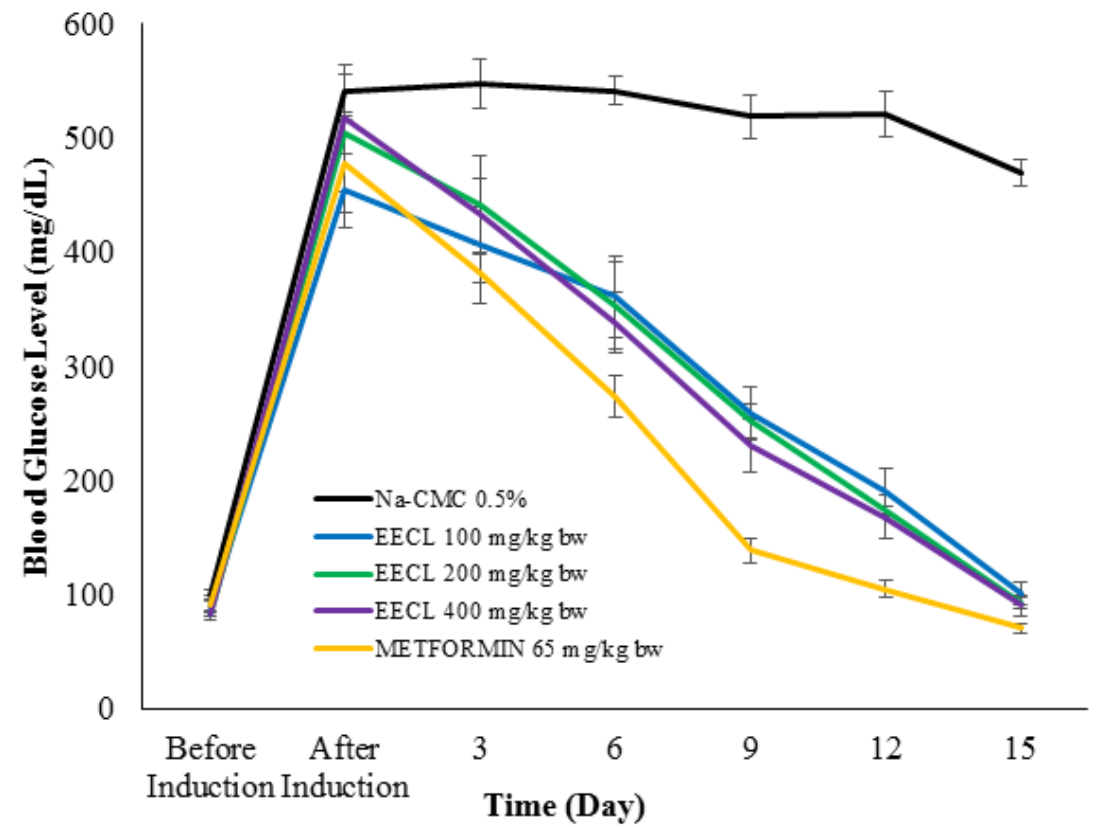

Fig.-1: Blood Glucose Level 
Flavonoids have hypoglycemic effects by several mechanisms, such as by stimulating insulin release or acting like insulin, inhibiting glucose absorption, increasing glucose tolerance, increasing glucose uptake by peripheral tissues and regulating enzymes that play a role in carbohydrate metabolism. ${ }^{10}$ Flavonoids are protective against beta-cell damage as an insulin producer and can increase insulin sensitivity. ${ }^{11}$ Polyphenols, and flavonoids are known to play a role in antioxidants and have the potential to attract free radicals. Previous research shows that total antioxidant activity and phenolic content in coriander extract both leaves and stems can be utilized as a source of important natural antioxidants with potential health protection. ${ }^{12}$

Alkaloids work by stimulating the hypothalamus which will induce hypoglycemia and reduce gluconeogenesis so that blood glucose levels and insulin requirements decrease. Alkaloids are also shown to have the ability to regenerate damaged pancreatic $\beta$ cells. Tanin has hypoglycemic activity by increasing glycogenesis, besides that, tannin also functions as chelating which shrinks the small intestinal epithelial membrane thereby reducing the absorption of food essence and as a result inhibits sugar intake and the rate of increase in blood sugar is not too high. ${ }^{13}$

Saponin can provide a hypoglycemic effect because it is able to regenerate the pancreas which causes an increase in the number of pancreatic and langerhans beta cells so that insulin secretion will increase. Increased insulin secretion will help reduce blood glucose levels. ${ }^{14}$ The ability of saponins to reduce blood glucose levels makes saponins a very good and efficient antioxidant in the remediation of diabetes mellitus. ${ }^{15}$

The pathological conditions of experimental animals do not fully describe real pathological conditions in humans. This is due to differences in physiological conditions, pathology of several models of diabetes mellitus, the variety of diabetes mellitus, and the existence of complications from the disease. ${ }^{16}$

\section{CONCLUSION}

Phytochemical screening of EECL showed the presence of many phytochemical compounds, such as alkaloids, flavonoids, tannins, glycosides, saponins and steroids. EECL also showed antihyperglycemic effect against alloxan induced in mice. It could be concluded that EECL has immense potential for developing a novel and safe treatment for diabetes.

\section{ACKNOWLEDGMENT}

The authors wish to thank Fransiska Arvianty for her help during this research. This study and publication were supported by the Universitas Sumatera Utara through "Hibah Penelitian Dasar Talenta" Research Grant 2019, Number: 138/UN5.2.3.1/PPM/2018/KP-TALENTA USU/2019 on 2 April 2019.

\section{REFERENCES}

1. R. Baishya, A. Adhikari, S. Biswas, S. Banerjee, Asian J. Pharm. Clin. Res., 11(3), 109(2018), DOI: 10.22159/ajpcr.2018.v11i3.23283.

2. F. Akter, M.M. Rahman, M. Mostofa, E.H. Chowdhury, Int. J. Curr. Res. Aca. Rev., 2(4), 124 (2014).

3. M. Rani, Y. Shailesh, C. Seema, S. Seema, M.P. Surya, International Journal of Health Sciences \& Research, 4(2), 68 (2014).

4. V. Chitra, S. Leelamma, Plants Foods Hum. Nutr., 51, 167(1997), DOI: 10.1023/A:1007975430328.

5. G. Haro, I. Iksen, R.M. Rumanti, N. Marbun, R.P. Sari, R.P.J. Gultom, Rasayan J. Chem.,11(1), 232 (2018), DOI: $10.7324 /$ RJC.2018.1112011.

6. S.M. Sinaga, S. Sudarmi, I. Iksen, K. Kevin, M.P. Sari, Rasayan J. Chem., 11(4), 1604 (2018), DOI: 10.31788/RJC.2018.1144067.

7. S.M. Sinaga, I. Iksen, G. Haro, S. Wardhany, Asian J. Pharm. Clin. Res., 11(3), 77 (2018), DOI: 10.22159/ajpcr.2018.v11i3.22851.

8. G. Haro, S.M. Sinaga, I. Iksen, N. Nerdy, S. Theerachetmongkol,J. App. Pharm. Sci., 7(8), 222 (2017), DOI: 10.7324/JAPS.2017.70830.

9. Y. Yusnita, M. Masfria, R. Rosidah, I. Iksen, Asian J. Pharm. Clin. Res., 11(7), 138 (2018), DOI: 10/22159/ajpcr.2018.v11i7.25023.

10. S.R. Handayani, P.T. Mahanani, Indonesian Journal of Medical Science, 6(1), 86 (2019). 


\section{RASĀYAN J. Chem.}

Vol. 12 | No. 4 |1992 - 1996| October - December | 2019

11. R.B. Ajie, J. Majority,4(1), 69 (2015).

12. E. Tansos, B.Pharm. Thesis, Department of Pharmaceutical Chemistry, University of Sumatera Utara, Medan, North Sumatera, Indonesia (2019).

13. O.M. Prameswari, S.M. Widjanarko, Jurnal Pangan dan Agroindustri, 2(2), 16 (2014).

14. M. Firdous, R. Koneri, C.H. Sarvaraidu, K.H. Shubbapriya, Journal of Clinical and Diagnosis Research, 3, 1460 (2009).

15. A.R.E. Barky, S.A. Hussein, A.E. Alm-Eldeen, Y.A. Hafez, T.M. Mohamed, Diabetes Manag., 7(1), 148 (2017).

16. A.E. Nugroho, Jurnal Biodiversitas UGM, 7(4), 378 (2006).

[RJC-5451/2019] 